\title{
Social Return on Education in 35 Cities/Districts of Central Java Province
}

\author{
By \\ Rr. Retno Sugiharti ${ }^{1 *}$, Gentur Jalunggono ${ }^{1)}$, Muhammad Farid Alfarisy ${ }^{2)}$ \\ ${ }^{1)}$ Faculty of Economic, Tidar University \\ 2) Faculty of Economics and Business, Jenderal Soedirman University \\ ${ }^{*}$ Corresponding Author : retno.sugiharti@untidar.ac.id
}

Submission: 16 April 2019, Accepted: 20 June 2019

\begin{abstract}
Education is closely related to the quality of labor. With good level of education, labor productivity will certainly increase. In addition to reducing poverty, productivity will boost economic growth. However, in Central Java Province the correlation between education and economic growth shows otherwise. Even though economic growth has increased quite well but society' 5 s average years of schooling is only six to seven years or up to elementary school. By using Mincer wage equation, this paper calculates social return on education within macroeconomic growth regression methods. This paper aims to examine the relationship between education attainment and economic growth. By estimating model derived from Mincer wage equation, we found that there is positive and significant relationships between Gross Fixed Capital Formation and Years of Schooling on Gross Regional Domestic Product. So, improvement in education has significant effect on economic growth.
\end{abstract}

Keywords: Economic Growth, Education, Mincer Wage Equation

\begin{abstract}
ABSTRAK
Pendidikan memiliki kaitan erat dengan kualitas tenaga kerja. Dengan tingkat pendidikan yang baik, produktivitas tenaga kerja tentu akan meningkat. Selain mengurangi kemiskinan, produktivitas akan meningkatkan pertumbuhan ekonomi. Namun di Provinsi Jawa Tengah korelasi pendidikan dengan pertumbuhan ekonomi menunjukkan kondisi yang berlawanan. Di Provinsi Jawa Tengah, pertumbuhan ekonomi meningkat cukup baik tetapi rata-rata lama sekolah hanya enam sampai tujuh tahun atau hanya sampai lulusan sekolah dasar. Dengan menggunakan Persamaan Upah Mincer, makalah ini mencoba untuk menghitung imbal hasil sosial atas pendidikan menggunakan metode regresi pertumbuhan ekonomi. Penelitian ini bertujuan untuk menguji hubungan antara pencapaian pendidikan dan pertumbuhan ekonomi. Dengan mengestimasi model yang diturunkan dari persamaan upah Mincer, kami menemukan hubungan positif dan signifikan antara Pembentukan Modal Tetap Bruto dan rata-rata lama sekolah, terhadap Produk Domestik Regional Bruto. Jadi, peningkatan pendidikan memiliki pengaruh signifikan terhadap pertumbuhan ekonomi.
\end{abstract}

Kata Kunci: Pertumbuhan Ekonomi, Pendidikan, Persamaan Upah Mincer 


\section{INTRODUCTION}

As the main driving force of the economy, labor has a very important role. But nowadays, paradigm of labor as production factor has shift over. The development of technology and industry is entering industry 4.0 and the requirement of labor in industry has developed from just a blue-collar labor trough labor with good qualification and knowledgeable. So that, we treat labor as non-physical investment instead of labor as factor input and it's called human capital.

The discussion on human capital was initiated by Becker (1961). Human capital or investment in human resources is a few funds or sacrifices incurred and opportunities to earn income during the investment process. Income during the investment process is expected to obtain a higher level of income to be able to achieve a higher level of consumption (Simanjuntak, 1985). The higher the quality of human resources, the higher the efficiency and productivity. Thus, human capital investment is believed to be the basis for increasing production factor productivity. Human capital is an embodied factor within each worker. So that, if the physical input factor can occur diminishing returns, but science wouldn't.

Drucker (2001)stated that the economy that prioritizes humans' factors is called a knowledgebased economy. In production theory, knowledge factors have been discussed in endogenous growth theory (P Romer, 1989; Paul Romer, 2001). The initial idea of endogenous growth theory boils down the investment return which decreases when there is an additional capital in the economy. This is believed as an effect of a using the new technology in the production process, although on the other hand it is realized that technology usages is the engine of economic growth. But then, technology usage in production (in this case its similar as knowledge) can encourage an increase in return on investment. In this side, we believe that knowledge is able to stimulate the efficiency of production methods. This will encourage the creation of new innovative and developing products. If new technology is proven to be able to increase return on investment, then investors will return to invest again in the field of technology or knowledge. This investment in the field of sustainable knowledge will ultimately drive a country's economic growth.

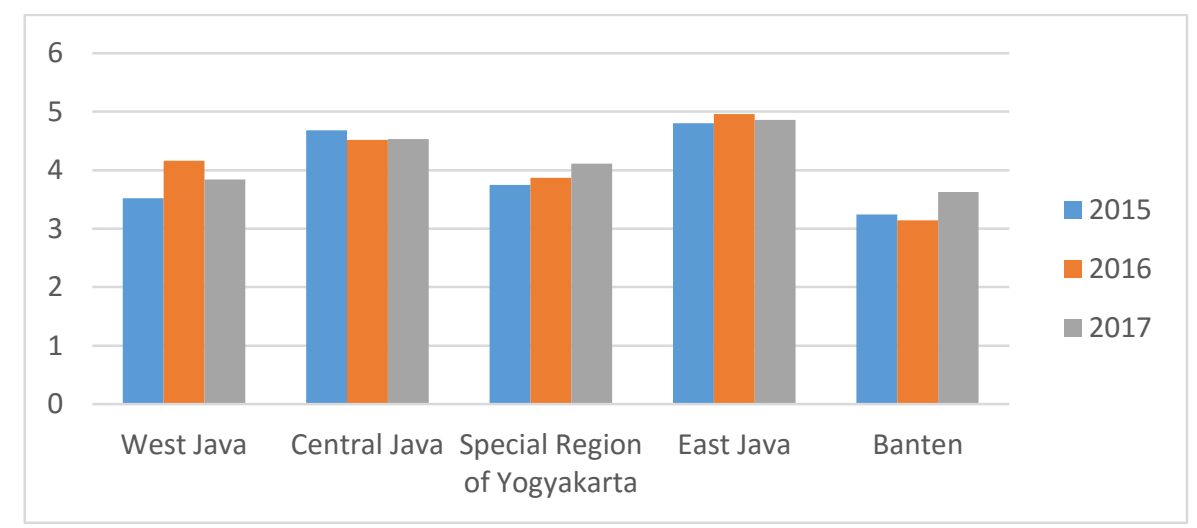

Figure 1. Rate of Growth in Gross Regional Domestic Product Per Capita at 2010 Constant Prices

(Percent)

Source: BPS, 2018

Figure 1 shows that as one of the provinces on the island of Java, Central Java experienced quite good economic growth. From 2015 - 2017, the average economic growth per capita in Central Java Province was 4.57 percent. It is in second place after East Java (4.87 percent) and is still above national average (3.71 percent). Surprisingly, Central Java is the province with the highest poverty reduction. 
As depicted in Figure 2, during 2009 to 2018 period, the number of people who lived in poverty in Central Java Province has decreased by an average of 4.56 percent per year.

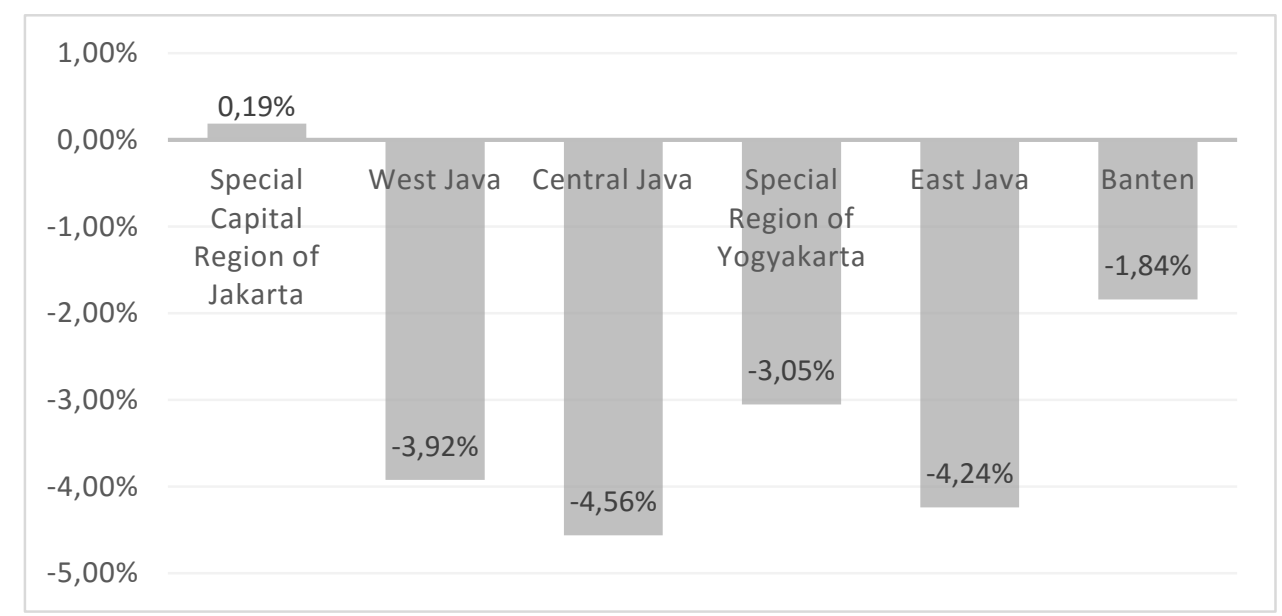

Figure 2. The Average Decline In The Number Of Poor People In Java In 2009-2018

Source: BPS Central Java, 2019

Theory of vicious circle of poverty state that poverty cause a person unable to access proper education. On the other side, if education rate is low then productivity is also low. So that the quality of education is the key for someone to enter the workforce and certainly will increase work productivity. The higher the productivity, the higher income will be. While the income level will determine whether he is able to access good education or not, and so on. So, to cut the poverty chain, mitigation measures can be taken, which is providing free access to education for the poor. Good quality of human resources will be easily absorbed by the labor market. In addition, it can be a driver of economic growth through product and technology innovations that generate productivity. High productivity ultimately triggers a country's economic growth. This leading us to make conclusion that, if poverty is low or the reduction of poverty is high is shows that education level is uprising, vice versa.

Education serves as a driving force for the transformation of society to break the chain of poverty. Education helps reduce poverty through its effects on labor productivity and through social benefit channels, so education is an important development goal for the nation (World Bank, 2005). Education is expected to gain insight, knowledge and skills so that employment opportunities are more open, and the wages earned are also higher. This important role of education has been well recognized by the government. Nowadays as one of educational policy to promote poverty mitigation through education based on Indonesian 1945 constitution article number 31(4), Indonesian government were mandated to set minimum education budget equal to $20 \%$ of national budget.

But lately if we look human capital indicator, it shows contradictory result. From the data we know that, the average length of schooling in Central Java Province is the lowest. The data will show down below (Figure 3): 


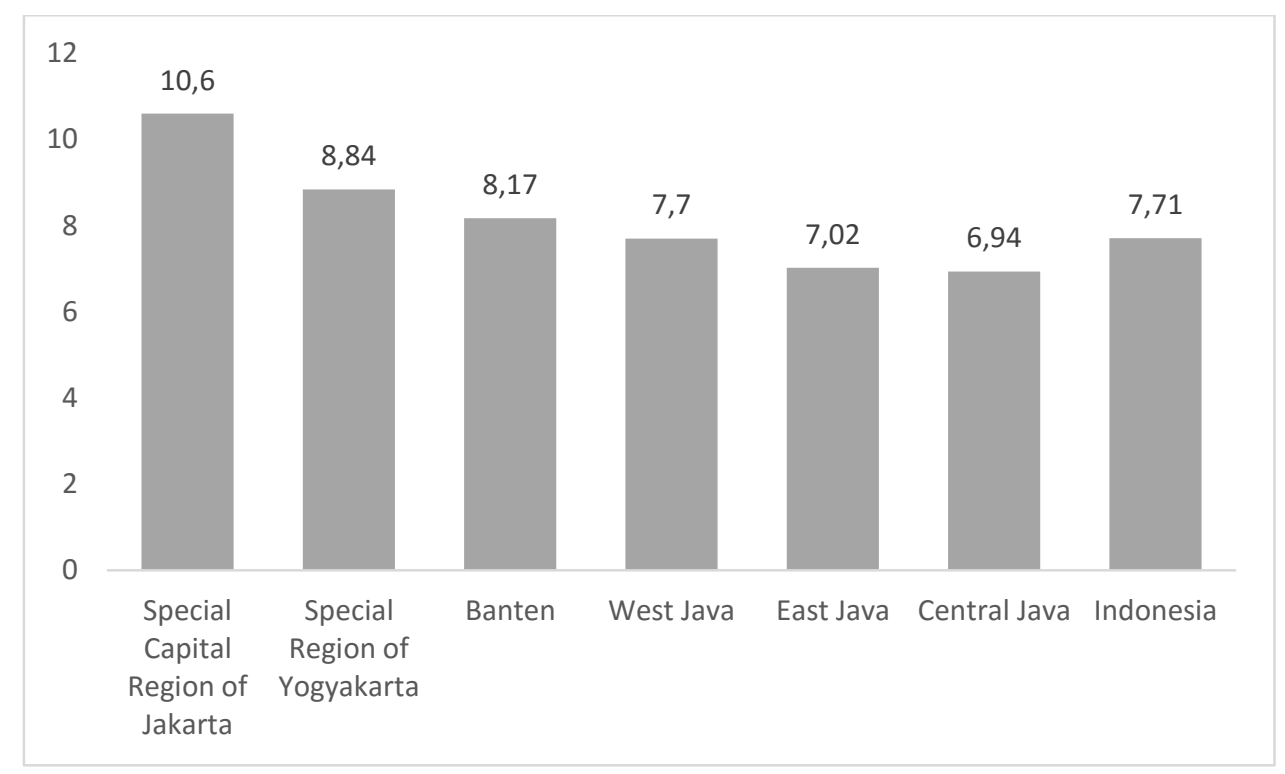

Figure. 3. Average Years of Schooling in Provinces in Java Island Source: BPS, 2019.

Table. 1. Average Years of Schooling in Provinces in Java Island

\begin{tabular}{lrrrrrrrrr}
\hline \multicolumn{1}{c}{ PROVINSI } & $\mathbf{2 0 1 0}$ & $\mathbf{2 0 1 1}$ & $\mathbf{2 0 1 2}$ & $\mathbf{2 0 1 3}$ & $\mathbf{2 0 1 4}$ & $\mathbf{2 0 1 5}$ & $\mathbf{2 0 1 6}$ & $\mathbf{2 0 1 7}$ & AVERAGE \\
\hline DKI Jakarta & 10.37 & 10.41 & 10.42 & 10.44 & 10.54 & 10.71 & 10.88 & 11.02 & 10.60 \\
DI Yogyakarta & 8.53 & 8.56 & 8.63 & 8.75 & 8.86 & 9.02 & 9.14 & 9.24 & 8.84 \\
Banten & 7.87 & 7.94 & 8.10 & 8.16 & 8.18 & 8.26 & 8.36 & 8.53 & 8.17 \\
West Java & 7.39 & 7.45 & 7.52 & 7.58 & 7.71 & 7.86 & 7.95 & 8.14 & 7.70 \\
East Java & 6.76 & 6.81 & 6.87 & 6.93 & 7.07 & 7.16 & 7.25 & 7.36 & 7.02 \\
Central Java & 6.73 & 6.76 & 6.79 & 6.82 & 6.94 & 7.05 & 7.17 & 7.29 & 6.94 \\
Indonesia & 7.40 & 7.47 & 7.55 & 7.62 & 7.74 & 7.85 & 7.96 & 8.11 & 7.71 \\
\hline
\end{tabular}

From Figure 3 and Table 1, the average length of workforce schooling rate in Central Java province is 6.94, meaning that the average education of workers in Central Java is equivalent to elementary school.

Some previous studies examining the role of human capital in economic growth such as De la Fuente \& Doménech (2006) who study the nexus of production and human capital, the results of the research shows a positive and significant correlation. Similar research was also carried out by Temple (1999) and Bassanini \& Scarpetta (2002)which revealed that each increase in school duration for one year caused an increase in GDP per capita by $6 \%$. Research from Á. De la Fuente \& Ciccone (2003)shows that in supporting human capital growth has a greater role in explaining productivity differentials between countries. Conducted research by Nelson \& Phelps (1966) and Funke \& Strulik (2000) also found that the process of adopting the development of technology from one country to another is strongly influenced by human capital.

However, when returning to the data, there is a tendency for contradictory conditions. This condition has been revealed by Levine \& Renelt (1992), Benhabib \& Spiegel (1994), Temple (1999), Bils \& Klenow (2000) in Pritchett (2001). In cross-country analysis, education does not have a significant impact on regression estimation that involve economic growth and education (Levine and Renelt, 1992). Besides that, human capital as a factor of production within the Cobb Douglas framework has been found to be insignificant in explaining GDP growth per capita (Benhabib and Spiegel, 1994). The effect of human capital on total factor productivity has an effect that can be seen in two aspects: first, human capital affects the level of innovation (in accordance with Romer (1990); second, human capital 
influences the rate of technology diffusion. Likewise, Dessus (2001) concluded that when education budget increases, the quality of education will decrease due to unequal distribution in educational services that hampered the efficiency of public expenditures. Similar research conducted by Bils and Klenow (2000) proves that the causality of education towards value growth is very weak, statistical significance in the regression between growth and human capital factors may arise from variables outside of the model.

Pritchett (2001) in his research, concluded three main factors that led to education as a measure of human capital did not affect economic growth. First, policies from the government can be quite contrary to reality. Second, marginal returns to education can decline rapidly as compensation for the supply of educated labour is expanding while the demand for educated labour is stagnant. Third, the quality of education can be so low that the length of school is not able to create human capital.

In terms of the theory of labour productivity, the inconsistencies that occur between output and the quality of human capital are caused by a positive correlation or strong correlation between the education level of workers and wages but there is no correlation between the level of education of workers and productivity. In other words, wage differences between levels of education do not reflect actual productivity differences. This is because the labour market cannot absorb educated labour, so the wages received by educated labour with non-educated labor are not much different. This explains why workers receive benefits and investments in education but at the same time an increase in the number of human resources has little effect on overall productivity. So that at the aggregate level, the contribution of human capital to the economy is very small or even insignificant (Pritchett, 2001).

When looking at Indonesia's economic data, the conditions in Indonesia especially in Central Java Province tend to support this contradictory statement. Indonesia's economic development experienced fluctuating growth with an increasing trend but the rate of output growth is not followed by an increase in quality of human capital.

The relationship of education with income was first conceived by Mincer (1974). Through the relationship of wages and education, Mincer (1974) explains that the meaning of the Mincer (1958) model is that the length of time to play is determinant of increasing income. That can be said that someone who has higher education has a higher chance of earning higher income than those who have lower education. In the macroeconomic scope, the coefficient of the education variable in the Mincer (1974) model shows social return. The social rate of return to education is the macroeconomic counterpart of the private return to education. The regular estimate of social return to education ranges between 5 and 15 percent (Carton, 2007) and another result from Soto (2002) said that the range of social rate returns of education is from 7 percent to 10 percent.

Based on the background above, this study will estimate the amount of social returns on education for all 35 districts / cities in Central Java Province.

\section{METHOD}

Measurements of educational investment are commonly made with wage variables although it should be remembered that in the short term the nature of wages is rigid and in the long run the nature of wages is flexible. If income or wages are interpreted as a function of investment in past human capital, the question that arises later is how much investment is chosen. Ben-Porath (1967) used the function of Human Capital Production (function of production of human resources) to formulate a Wealth Maximization Model. With a fundamental idea that individuals will try to get maximum wealth throughout their lives. This assumption in the Ben-Porath (1967) as in Mincer (1974) model is that the labor supply is constant all the time, human capital stock depreciate over time, workers are able to allocate their time and activities to work and attend school or attend training, education and training are able to produce stock of human capital that will increase marginal productivity of labor but at some point increased in stock of human capital will decrease labor productivity. 
Based on the wage theory of Ben Porath (1967), Mincer $(1958,1974)$ developed a regression model to explain the factors that determine wages in the labor market. The frame of the Mincer model is as follows:

$$
\operatorname{Ln}[Y(S, A)]=\alpha_{0}+\alpha_{1} S+\alpha_{2} A+\alpha_{3} A^{2}+\varepsilon
$$

Where:

$\operatorname{Ln} Y$
$S$
$A$
$A^{2}$
$\alpha_{0}$
$\alpha_{1}$
$\alpha_{2}, \alpha_{3}$
$\boldsymbol{\varepsilon}$

$=$ Wage Logarithmic Value

= years of schooling

= potential work experience

= square of potential work experience

$=L n W_{0}$ coefficient

= coefficient of schooling

= experience coefficient (work experience) in linear an quadratic

$=$ mean zero residual

The equation above known as the Mincer Wage Equation. While the value of rate of return education investment is assumed to be the same for all education levels and is obtained from the $S$ $\left(\alpha_{1}\right)$ coefficient value.Assuming, the value of the schooling coefficient, $\alpha_{1}$ is the same as the discount rate.The regression coefficient $\alpha_{1}$ on years of schooling $\mathrm{S}$ can be interpreted as the social return to education.

The advantages of Mincer's function are explained by Krueger and Lindahl (2001) in their argument that in the Mincer (1974) model it has been shown that if an additional one-year school period is a student's opportunity time and if the additional proportion of time is constant, income (log) will be linearly related to the individual school year; and the slope of this relationship can be seen as a rate of return. On this basis, years of schooling can be used in estimating return to education and in years of schooling can compare across countries, even with different education systems (Krueger), 1999: 6).

Furthermore, saying that the income model from Mincer is the foundation for economic studies in developing countries for several reasons (Heckman, Lochner, and Todd, 2006). First, this model is the basis for calculating the rate of return on education. Second, Mincer income models are a basis for estimating the quality of education returns. In addition, the Mincer revenue model can be used flexibly where the model can be modified by adding control variables that can theoretically affect income. Then this model is still relevant to use today (Lemieux, 2006).

However, the Mincer income model also has several disadvantages, namely this model does not include treatment of variable bias, measurement errors such as experience, shifts in decisions underlying a person for school and not considering uncertainty factors in estimating individual income in the future (Heckman, Lochner, and Todd, 2013).

In estimating social return on education, we will use the economic growth model. Since human capital emerged, this factor has been considered by economists as one of the factors of production. Mankiw, Romer, \& Weil (1992) first introduced human capital and added it to the production factor. This study will adapt the equation model from Canton (2007) and Soto (2006). The MRW production function is written as follows:

$$
Y_{i t}=A_{i t} K_{i t}^{a}\left(h_{i t} L_{i t}\right)^{1-\alpha}
$$

In this study the human capital estimate is carried out using the Mincer Equation approach, as in the equation above, written as:

$$
\ln h_{i t}=r S_{i t}+\alpha \operatorname{Exp}_{i t}+\alpha E x p 2_{i t}
$$

Where $r$ is the return to education and $S$ is educational attainment. Exp (Experience) is work experience and Exp2 is square of work experience. The growth rate of the labor force will vary across 
district or cities and over time, but technological progress $g$ and physical capital depreciation are assumed to be constant. It can be shown that the testable empirical model is then given by:

$$
\log \left(y_{i t}\right)=\frac{a}{1-a}\left[\log S_{i t}-\log \left(n_{i t}+g+d\right)\right]+\left(S_{i t}+\alpha E x p_{i t}+\alpha E x p 2_{i t}\right)+\frac{\left(\boldsymbol{h}_{\boldsymbol{i t}}+\boldsymbol{t}_{\boldsymbol{i t}}+\boldsymbol{e}_{i t}\right)}{(\mathbf{1}-\boldsymbol{a})}
$$

Since the first term in brackets on the right-hand side is also referred to as adjusted investments, so the model can be simplified as:

$$
\log \left(y_{i t}\right)=\ln k+S_{i t}+\alpha \operatorname{Exp}_{i t}+\alpha \operatorname{Exp} 2_{i t}
$$

Noted that $y_{i t}$ is $Y / L$ refers to income per worker or productivity.

This study uses quantitative data collected from the Central Bureau of Statistics with observation objects in 35 Central Java district/cities during the period of 2010 -2017. Data were analyzed using panel regression with fixed effect method. The variables used in this study are as follows:

(1) Growth of Output (LnOutput) is real Gross Regional Domestic Product (GRDP)

(2) Stock Capital ( $k$ ) is allocation of Gross Fixed Capital Formation (GFCF)

(3) Human Capitalis proxy by education attainment which is Years of Schooling (YOS)

(4) Experience(Exp) isPotential Work Experience (Life Expectancy - YOS - 6)

(5) Square Experience (Exp2) is the value of the square of potential work experience

In the econometric equation, the model to be estimated is as follows:

$$
\text { lnOutput }_{i t}=\beta_{0}+\beta_{1} \operatorname{lnGFCF}_{i t}+\beta_{2} \text { YOS }_{i t}+\beta_{3} \operatorname{Exp}_{i t}+\beta_{4} \operatorname{Exp2}_{i t}+\varepsilon_{i t}
$$

\section{RESULT AND DISCUSSION}

Descriptive statistical analysis is used to provide an overview of data. Data in this study consist of 280 observations that were obtained from 35 districts or cities and eight years of time period during 2010 to 2017. In this descriptive statistical analysis, calculated the average value, standard deviation, minimum value, and maximum value of the research variables. The results of descriptive statistics can be seen in Table 2 as follows.

Table 2. Summary of Descriptive Statistic

\begin{tabular}{lrrllr}
\hline \multicolumn{1}{c}{ Criteria } & InOutput & InGFCF & \multicolumn{1}{l}{ YOS } & \multicolumn{1}{l}{ Exp } & \multicolumn{1}{c}{ Exp2 } \\
\hline Mean & 3.705590 & 6206480. & 7.163393 & 61.23332 & 3751.886 \\
Median & 3.528299 & 4562099. & 6.850000 & 61.41000 & 3771.188 \\
Maximum & 5.047206 & 36122660 & 10.50000 & 64.00000 & 4096.000 \\
Minimum & 2.874319 & 1126409. & 4.940000 & 56.04000 & 3140.482 \\
Std. Dev. & 0.523638 & 5895527. & 1.276905 & 1.540954 & 186.6359 \\
Skewness & 1.036052 & 2.875966 & 1.088203 & -0.893003 & -0.800374 \\
Kurtosis & 3.015108 & 11.27815 & 3.537480 & 4.260533 & 3.978402 \\
Jarque-Bera & 50.09483 & 1185.478 & 58.63237 & 55.75221 & 41.06271 \\
Probability & 0.000000 & 0.000000 & 0.000000 & 0.000000 & 0.000000 \\
Sum & 1037.565 & $1.74 \mathrm{E}+09$ & 2005.750 & 17145.33 & 1050528. \\
Sum Sq. Dev. & 76.50096 & $9.70 \mathrm{E}+15$ & 454.9059 & 662.4966 & 9718394. \\
Observations & 280 & 280 & 280 & 280 & 280 \\
\hline
\end{tabular}

The results of the descriptive statistical analysis in Table 2 shows that in the absolute value of the mean on the five variables, the value is greater than the standard deviation value. The standard deviation value describes how far the data varies. If the standard deviation value is far greater than the mean value, then the mean value is a poor representation of the entire data. Whereas if the 
standard deviation value is very small compared to the mean value, the mean value can be used as a representation of the overall data.

Although based on assumptions, the best panel regression model in this study is a fixed effect, but statistical tests are still carried out to select the method to be used to avoid bias in the model. To choose the best model between the Fixed Effect model and Random Effect Model, the Hausman test is used. Hausman test results are presented in Table 3.

Table 3. Hausman Test

\begin{tabular}{cccl}
\hline Model & P-Value & Decision & \multicolumn{1}{c}{ Model } \\
\hline InOutput $=f\left(\right.$ InGFCF,YOS,Exp,Ex $\left.{ }^{2}\right)$ & 0.0060 & $<0.05$ & Reject $\mathrm{H}_{0}$ \\
& & & (Fixed Effect Model) \\
\hline
\end{tabular}

Some classical assumption problems found in the main model, the existence of heteroscedasticity and autocorrelation cause the panel regression model to be biased. To overcome this problem a robust standard error method is used. The robust standard error method used is in this research is period weights standard errors (PCSE) \& covariance (d.f. corrected). By using Eviews v.10, the regression results are as follows:

Tabel 4. Regression Estimation of Fixed Effect Method

\begin{tabular}{lrrrr}
\hline \multicolumn{1}{c}{ Variable } & Coefficient & Robust Std. Error & t-Statistic & Prob. \\
\hline LnGFCF & 0.342837 & 0.027283 & 12.56606 & 0.0000 \\
YOS & 0.249184 & 0.017065 & 14.60198 & 0.0000 \\
Exp & -0.071834 & 0.651347 & -0.110286 & 0.9123 \\
$\quad$ Exp2 & 0.000781 & 0.005400 & 0.144723 & 0.8851 \\
$\quad$ C & -1.888126 & 19.69595 & -0.095864 & 0.9237 \\
\hline R-squared & 0.753960 & & & \\
Adjusted R-squared & 0.715165 & & & \\
S.E. of regression & 0.279465 & & & \\
Sum squared resid & 18.82233 & & & \\
Log likelihood & -19.33839 & & & \\
F-statistic & 19.43457 & & & \\
Prob(F-statistic) & 0.000000 & & & \\
\hline
\end{tabular}

From the regression results, the Adjusted R-squared value is 0.715 , indicating that $71.5 \%$ of the independent variables affect the dependent variable, while $28.5 \%$ of the independent variables are influenced by other variables outside the model. At the $1 \%$ significance level, the goodness of fit test indicated by the F-statistic value shows a value of 19.43457, this value indicates that the model has been correctly specified.

Estimation results on each independent variable, the first is LnGFCF shows a significant positive relationship to In Output with a t-statistic value of 12.56606 significant at level $1 \%$. The LnGFCF elasticity shows that 1 percent of the increase in LnGFCF will increase the output of 0.342 percent, ceteris paribus. Then the Schooling (YOS) variable has a significant effect on LnOuput shown by the tstatistic value of 14.60198 significant at level 1\%. Whereas YOS elasticity indicates that 1 percent increase in YOS will increase output by 0.249 percent, cateris paribus. While Variable Experience (EXP) and Square Experience (Exp2) did not have a significant effect on LnOutput.

The YOS coefficient $\left(\beta_{2}\right)$ is a social return on education, where the value generated from the estimation above is 0.249184 . As stated by Canton (2007) that the value of social rate of education will be worth between 5-15 percent, so the estimation made in this study that the value of social rate of education ( $r$ ) is 24.91 percent. Canton (2007) reminds us to notice that the macro Mincer specification assumes a linear relationship between the logarithm of human capital and years of schooling, so the 
point estimates are semi-elastic. The log-linear formulation suggests that each additional year of schooling of the labor force increases productivity by $r$ percent.

\section{CONCLUSION}

Combining micro and macro methods is a new and quite difficult things to do. This study discusses the Mincer method, the equation based on micro methods with economic growth. In terms of the model, this study has produced a good model for estimation.

From social capital (human capital) side, the potential of work experience in both linear and quadratic forms does not have a significant effect on output. The results of social estimation to education show a higher value than the average estimated value of previous studies, which amounted to 24.91 percent.

In the other side, if we return to the data, the low quality of human capital as indicated by the low quality of graduates of labor opposite to high productivity growth. Considering that fact, this study only calculates social return to education, then in the next study it is better to calculate the private return to education. This finding supports of the findings from Bassanini \& Scarpetta (2002), De la Fuente \& Ciccone (2003), and De la Fuente \& Doménech (2006).

What we need to note in this research, that improving education or increasing human capital has a significant effect on economic growth. And we can conclude that in this term of sample education is a determinant factor of economic growth.

\section{REFERENCES}

Bassanini, A., \& Scarpetta, S. (2002). Does Human Capital Matter For Growth In OECD Countries? A Pooled Mean-Group Approach. Economics Letters, 74(3), 399-405.

Becker, G. S. (1961). Investment in Human Capital. The American Economic Review, 51(1), 1-17.

Benhabib, J., \& Spiegel, M. (1994). The Role of Human Capital in economic Development Evidence from Agregate Cross-Country Data. Journal of Monetary Economics 34 (1994) 143-17, 144(34), 14317.

Bils, M., \& Klenow, P. J. (2000). Does Schooling Cause Growth? American Economic Review, 90(5), $1160-1183$.

Canton, E. (2007). Social returns to education: Macro-evidence. Economist, 155(4), 449-468.

De la Fuente, Á., \& Ciccone, A. (2003). Human Capital In A Global And Knowledge-Based Economy. Employment \& social affairs (Vol. 1).

De la Fuente, A., \& Doménech, R. (2006). Human Capital in Growth Regressions: How Much Difference Does Data Quality Make? Journal of the European Economic Association, 4(1), 1-36.

Dessus, S. (2001). Human Capital And Growth: the Recovered Role of Education Systems. Policy Research Working Paper ; 2632, (972 2), 22.

Drucker, P. F. (2001). The Next Society. The Economist, November 3.

Funke, M., \& Strulik, H. (2000). On Endogenous Growth with Physical Capital, Human Capital and Product Variety. European Economic Review, 44(3), 491-515.

Levine, R., \& Renelt, D. (1992). A sensitivity analysis of cross-country growth regressions. American Economic Review Pp, 82(4), 942-963.

Mankiw, G. N., Romer, D., \& Weil, D. N. (1992). A Contribution to the Empirics of Economic Growth Author. The Quarterly Journal of Economics, 107(2), 407-437.

Nelson, R. R., \& Phelps, E. S. (1966). Investment in humans, technological diffusion, and economic growth. American Economic Review, 56(2), 69-75.

Romer, P. (1989). Human capital and growth: theory and evidence, (3173), 51.

Romer, P. (2001). Comment on "It's Not Factor Accumulation: Stylized Facts and Growth Models," by William Easterly and Ross Levine. The World Bank Economic Review, 15(2), 225-227.

Simanjuntak, P. J. (1985). Pengantar Ekonomi Sumber Daya Manusia.

Soto, M. (2006). Estimating the Social Return on Schooling. In International Conference on Human and Economic Resources (pp. 43-65). Izmir. 
Social Return on Education .... (Sugiharti, et al.)

Temple, J. (1999). A Positive Effect of Human Capital on Growth. Economics Letters, 65(1), 131-134. 